\title{
COMPARATIVE ANALYSES OF PREPOSITONS IN JAPANESE AND UZBEK LANGUAGES
}

\section{Sitorabonu Farxodovna Malikova}

Teacher, Uzbekistan State World Languages University

\section{ABSTRACT}

In linguistics, the comparison of languages has always been in the center of attention. Although it is recognized by scholars that Japanese and Uzbek belong to the same language family, the Altaic language family, grammatical phenomena in both languages are not the same. While both languages have similarities, they also have differences. Comparing languages belonging to the same language family involves studying the phenomena that occur in that language. The category of agreement is widely observed in both languages, but there are some agreements between Japanese agreement agreements, which are given with one agreement in Uzbek, and the scope of application is narrow. The category of consonants is widely observed in both languages, but there are some consonants among the Japanese suffixes, which are given with one consonant in Uzbek, and the scope of application is also narrow. This article provides a comparative analysis of the Uzbek suffix of the accusative case and the differences between them

KEYWORDS: - agreement; [ni] agreement suffix; [e] the suffix of agreement; morphological means; space.

\section{INTRODUCTION}

Due to the fact that the Japanese language belongs to the family of Altaic languages, there are many similarities with the grammar of the Uzbek language. Although both languages belong to the same language hierarchy, Japanese is a separate group. Uzbek belongs to the group of Turkic languages. Although there are grammatically similarities in both languages, there are also differences, as no two languages are identical in all respects. Differences in both languages are also reflected in the agreements.

\section{THE MAIN FINDINGS AND RESULTS}

In Japanese, conjunctions are called suffixes and are called kakujoshi, meaning that they perform the function of a suffix. In Japanese, there are は and がsuffixes, and in some cases no suffixes. In the Uzbek language there is no suffix. which encourages the analysis of different situations in both languages?

(1) は (although it is written as ha, it is pronounced as wa) In the comparative analysis of the function of the suffix in the sentence with the Uzbek language the following can be given:

は (va) as an adjunct to the main clause, the main part of the sentence serves to express the subject of the sentence. The main consonant that expresses the subject is what is known to the speaker and the listener in the sentence, the information is the "subject". For example, 
CURRENT RESEARCH JOURNAL OF PHILOLOGICAL SCIENCES 2(5): 117-

121, May 2021 DOI: https://doi.org/10.37547/philological-crjps-02-05-25

ISSN 2767-3758

(C)2021 Master Journals

\section{Crossref do) 81 Google}

Accepted25 $5^{\text {th }}$ May, 2021 \& Published 31 $1^{\text {th }}$ May, 2021

彼は有名な大学の学生です (1)。

Kareva yu:meina daigaku-no gakusei des.

Uø is a student at a famous institute. (Who is he?)

Although the Uzbek language does not have a suffix, it is functionally close to the Uzbek language. Since the concept of topic is one of the most pressing issues, in some literatures it is called xì zhùcí, not a suffix. Because it is said that it has the ability to give meaning by completing the verb.

In addition to the possessive part in $は$ sentences, it is used to express the topic you want to emphasize, as well as to describe the old information in the sentence.

$$
\text { ここに桜の花がたくさんさきます。あの桜は咲 }
$$$$
\text { くと、一番うれしくなります。0 Koko-ni }
$$
sakura-no hana-ga takusan sakimas. Ano sakurava sakuto, ichiban ureshiku narimas.

Sakura opens a lot here. I would be very happy if that sakura tree blossomed.

In the first part of the sentence he gives an overview of the sakura, and in the second part of the sentence he mentions a sakura tree. He also says that the word is not new, because in the first part of Gao there is a sakura tree.

In Japanese, there are special consonantal clauses that indicate the subject and rhyme, but in Uzbek there is no clause. As you know, the sentence is followed by the rema parts, so they are also called "logical-grammatical divisions". On this basis, in Uzbek it is expressed as follows. For example,

Jamshid maktabga ketdi.

Jamshid went to school.

In this sentence, Jamshid represents a certain part of the sentence - the subject, and the new part of the sentence - rema, which went to school.
There are more than はspecific features of the agreement, and a number of researchers are still working on it. Since it is one of the はmultifunctional indicators, its only function as an agreement indicator is to be able to perform the function it has in a sentence and interact with the cut. Many linguists refer to it as both an auxiliary and a consonant, which cannot be given in translation by a single morpheme, so it differs from the main consonant in Uzbek in form, but is close in syntactic function. costs Another feature is that はreceipts can come in place of the ““を(o)””, which is an agreement indicator (the remaining agreements are presented in the following paragraphs). The Uzbek language does not have this phenomenon. There is no change in the meaning of the sentence. Compare:

この家は息子が建てたーこの家を息子が建てた

[Kono ie-va musuko-ga tateta - kono ie-o musuko-ga tateta]

O'g'lim bu uyni qurgan.- Bu uyni o'g'lim qurgan. My son built this house. - This house was built by my son.

Although 家は ie is replaced by 家をie-o in the sentence and $は$ in the word, it has no effect on the meaning of the sentence, but the owner of the sentence is 家in the first sentence, indicating the subject in the first sentence. He is the owner of 息子がsentences. Although the translation is almost identical in Uzbek, it can be divided according to the emphasis.

This means that the $は$ consonant indexes differ in form from the main consonant in the Uzbek language, and are similar in general syntactic function.

(2)が (ga) - the main rheumatic agreement - the information that is new to the listener in the sentence - "rema". Rema is が (ga). Lavrentev called imenitelnyy padezh (rematicheskiy). が Who is the main agreement? what? answers 
CURRENT RESEARCH JOURNAL OF PHILOLOGICAL SCIENCES 2(5): 117-

121, May 2021 DOI: https://doi.org/10.37547/philological-crjps-02-05-25

ISSN 2767-3758

(C)2021 Master Journals

\section{Crossref do) 81 Google}

Accepted25 $5^{\text {th }}$ May, 2021 \& Published 31 ${ }^{\text {th }}$ May, 2021

questions and plays a key role in speech. For example,

$$
\text { 花子さんが学生です。Hanakosan-ga gakusei }
$$
des.

Hanako - talaba. (talaba kim?) - Hanako - student. (who is the student?)

In this sentence, the possessive of 花子さん sentences is represented by the rema figure and represents a predicative relation with 学生ですnouns.

In addition to the role of the owner, the complement in the speech can also come in an objective attitude. In this case, the cut should be semi-predicative verbs in Japanese that express the physiological and psychological state (すき suki - to like, きらいkirai - to hate, ほしいhoshii - to want). For example,

花がほしいです。Hanaga hoshii des - I would like a flower;

本が好きです。Honga suki des - I like the book;

Here, the 花が, 本がwords represent the object in the sentence. This event corresponds to the task of the Uzbek language. The がcompromise indicators form an objective relationship between 花and ほしいです.

The intonation is also used in speech, which comes in がgeneral consonants. The word is pronounced aloud. For example, like 本がヤ好きです.

It is also important to distinguish the がconjunctions that serve to separate sentences in Japanese from the がconsonants.

Although there is a general consonant suffix are similar to each other, 野田can be distinguished on the basis of the following four different rules.

がis added to the possessive part in the expression of the old information, and $は$ is added to the possessive part in the expression of the old information, e.g.

昔々、おじいさんとおばあさんがおった。おじ いさんは山へ芝刈りに、おばあさんは川へ洗濯 に行った。

[Mukashi mukashi, Ojīsan to obāsan ga otta. Ojīsan wa yama e shiba-gari ni, obāsan wa kawa e sentaku ni itta]

In ancient times there was an old man and an old woman. The old man went up the mountain to gather fire, and the old woman went to the river to wash her clothes.

In the first part of this sentence, the fact that he is talking about the old man and the old woman for the first time is expressed by the general agreement that gives information. In the second sentence, the words "old man" and "old woman" are given for the first time with は thematic consonants.

- It is observed that the phenomenon is given by がif it expresses the basis of the concept, and by はwhen it expresses the sentence. For example,

1. 雪が降っている。Ame-ga futte iru. Yomg`ir yog yapti - It is raining;

2.あの桜はとてもきれいだ。Ano sakura-va totemo kireida. - Ana u sakura guli judayam chiroyli. - That sakura flower is so beautiful.

In the first sentence, the speaker does not mix his feelings and thoughts, that is, he manifests himself as a phenomenon, and in the second sentence, the speaker calls the flowering of "sakura" "very beautiful" expresses a feeling. However, in the Uzbek language these cases and events are expressed in the same way, and the general agreement does not receive any additions in the same case. In sentence (2) there are also あの index pronouns. It should be noted that, and the main consonant suffix is always represented by show pronouns. 
CURRENT RESEARCH JOURNAL OF PHILOLOGICAL SCIENCES 2(5): 117-

121, May 2021 DOI: https://doi.org/10.37547/philological-crjps-02-05-25

ISSN 2767-3758

(C)2021 Master Journals

Crossref dof 81 Google

Accepted25 $5^{\text {th }}$ May, 2021 \& Published 31 ${ }^{\text {th }}$ May, 2021

- Also, in Japanese, a noun denoting an adjective in a sentence is represented by $は$, and in the adjective there is a suffix が ga. For example,

きのう、彼女が作ったケーキは、おいしかった

Kinou, kanojo-ga tsukutta ke-ki-va, oishikatta.

Kecha u pishirgan shirinlik, mazali edi. // The dessert she cooked yesterday was delicious.

In this case it is observed that the dessert (pie) is given to the owner of the sentence, taking the suffix は, Who cooked it? The answer to that question comes with 彼女 (kanojo) が. In this case, it is also expressed by the addition of ga to emphasize that it is cooked. In the Uzbek language, these cases are given as the owner of a single consonant, and what was delicious? Everyone will answer the question. It also does not receive any supplements.

- When comparing two objects, both are added to the possessive part of the sentence. For example,

お茶は飲めますが、コーヒーは飲めません

Ocha-va nomemas-ga, ko-hi-ha nomemasen.

Choy icha olamanu, qavha icha olmayman.// I can't drink tea, I can't drink coffee.

In this case, coffee and tea, which belong to the same group, are compared, and the speaker lists whether one can drink or not.

In the Uzbek language, as noted above, it is not expressed by any suffix.

\section{Conclusion}

From the above, it can be concluded that a comparative analysis of the general agreement in Japanese and Uzbek languages shows that the general agreement in Japanese forms a unique system. This system, on the other hand, reveals its narrow range of differences. In this article, it is mainly observed in the narrow context of the general agreement. Thus, no matter how wide the scope of the use of the suffix in the Japanese language, in the grammar of the Uzbek language compared today, this situation is not observed and does not take any suffix.

\section{ReFERENCES}

1. 庵

功雄2001『新しい日本語学入門ことばの

しくもを考える」ズリーエネットワーク

』142p.

2. 庵

功雄・高梨信乃 - 中西久美子 - 山田敏弘 2001 『中上級を教える人のための日本語 ハンドブック』600p.

3. 庵功雄 - 高梨信乃 - 中西久美子 - 山田敏 弘2000『初級を教える人のための 日本語ハンドブック』株式会社 $443 p$.

4. 竹内美智子1973『副詞とは何か」 『品詞別

日本文法講座 5 』明治書院198p.

5.上級レベルニュウアプロチ2002東京 $258 \mathrm{p}$.

6. 森山新 2008 『日本語習得・教育研究への 認知言語学の応用可能性』論文 $12 p$.

7. 石綿敏雄1990『対照言語学』桜風社 $200 \mathrm{p}$.

8. 入江相政1981『生き行きて』中英公論社 $-15 p$

9. Zikrillaev G. (1994) Morphology of the Uzbek language. - Bukhara: - p. 163. (Зикриллаев Ғ. Ўзбек тили морфологияси. - Бухоро: нашриётсиз, 1994. $-163 б$.

10. Khayrullaev Kh. (2001) Word, phrase and relation of sentence to predicative: 
CURRENT RESEARCH JOURNAL OF PHILOLOGICAL SCIENCES 2(5): 117-

121, May 2021 DOI: https://doi.org/10.37547/philological-crjps-02-05-25

ISSN 2767-3758

(C)2021 Master Journals

Crossief do) 88 Google

Accepted25 ${ }^{\text {th }}$ May, 2021 \& Published 31 ${ }^{\text {th }}$ May, 2021

Candidate of Philological Sciences. Diss. Samarkand: - p. 138. (Хайруллаев Х. Сўз, сўз бирикмаси ва гапнинг предикативликка муносабати: Филол. фан. номз...дисс. - Самарқанд, 2001. 1386.)

11. Khudaybergenova Z. (2007) Scientific interpretation of monotaxems in Uzbek and Turkish languages: Candidate of Philological Sciences. Diss. - Tashkent: - p. 300. (Худайбергенова 3. Ўзбек ва турк тилларидаги монотаксемаларнинг илмий талқини: Филол. фан. ном...дисс. - Тошкент, 2007. -300б.)

12. Hojiev A. (2002) Annotated Dictionary of Linguistic Terms. - Tashkent: National encyclopedia of Uzbekistan. - p. 163. (Хожиев А. Тилшунослик терминларнинг изохли луғати. -Т.: Ўзбекистон миллий энциклопедияси, 2002. -163 б.)

13. Sayfullaeva R. and others. (2009) Modern Uzbek literary language. - Tashkent: Teacher. - p. 383. (Сайфуллаева Р. ва бошқалар. Хозирги ўзбек адабий тили. Т.: Ўқитувчи, 2009. -Б.383.)

14. Хадсон, Рикуко Эндо, Джунко Кондо, Йошими Сакакибара. Mu joshi no shudai shugo mokuteki-go. 2001. - p. 104. 